\title{
Analisis Capital Asset Pricing Model (CAPM) Sebagai Dasar Pengambilan Keputusan Berinvestasi Saham (Studi pada Indeks Bisnis-27 di Bursa Efek Indonesia)
}

\author{
Nurain Hasan \\ Frendy A. O. Pelleng \\ Joanne $V$. Mangindaan \\ Jurusan Ilmu Administrasi Program Studi Ilmu Administrasi Bisnis \\ Fakultas Ilmu Sosial dan Politik Universitas Sam Ratulangi \\ Email : ayinhsnn@gmail.com
}

\begin{abstract}
The purpose of this study were: (1) To help investors pick efficient and inefficient stocks, (2) Investors know which stocks that have an optimal return and appropriate risk, (3) Investors know about CAPM metodh in determining the best investment decisions. CAPM is a model for estimating returns earned on risky securities or as a benchmark in evaluating the rate of return on an investment. The samples were selected by purposive sampling technique, the samples were determined by the specific criteria: (1) Companies listed on the Indonesia Stock Exchange belonging to the Business-27 stock index (2) Companies whose shares are included in the Business-27 stock index consistenly. The selection criteria in this study is choosing the efficient stocks in which individual return > expected return (Ri>ERi). Efficient collection of shares must be a priority in investment decisions made only efficient stocks that can be purchased. The results of this study indicate that: There are 18 stocks included on Efficient shares ie AKRA, BBCA, BBNI, BBRI, BMRI, CPIN, GGRM, INDF, INTP, PGAS, SMGR. These shares have a Ri> ERi value, investment decisions should be taken by investors was to buy efficient stocks. Based on data analysis there is a non-linear relationship between systematic risk and expected stock returns.
\end{abstract}

Keywords: CAPM, beta, stock, Business-27 Index

\section{Pendahuluan}

Dalam dunia investasi para investor harus mampu melihat peluang investasi yang menjanjikan, sehingga nantinya investasi tersebut dapat menghasilkan tingkat pengembalian yang optimal dengan tingkat risiko yang minimal. Cara yang dapat membantu investor menentukan investasi di pasar modal, salah satunya dengan menggunakan model-model keseimbangan dalam menentukan risiko dan tingkat pengembalian yang diharapkan suatu aset. Capital Asset Pricing Model (CAPM) merupakan salah satu model yang dapat menghubungkan tingkat return harapan dari suatu aset berisiko dengan risiko dari aset tersebut pada kondisi pasar yang seimbang.

CAPM bertujuan membantu investor dalam melakukan seleksi saham dan meminimalisir investasi yang berisiko. Penggunaan CAPM diharapkan dapat 
membantu investor untuk menggambarkan kondisi pasar yang bersifat kompleks, serta memperkecil risiko investasi dan mengestimasi besarnya return yang diperoleh.

Investor yang rasional akan lebih memilih saham efisien yaitu saham yang memiliki return ekspektasi lebih kecil daripada return yang sebenarnya. "Saham efisien dapat ditentukan dengan memilih tingkat return ekspektasi tertentu, kemudian meminimumkan risikonya atau meminimumkan tingkat risiko tertentu, kemudian memaksimalkan return ekspektasinya" (Tandelilin, 2010). Saham tidak efisien adalah saham yang harus dihindari karena saham tersebut memiliki tingkat pengembalian individu yang kecil dibanding dengan return yang diharapkan. CAPM juga dapat membantu investor dalam menghitung risiko yang tidak dapat diversifikasi dalam suatu portofolio dan membandingkannya dengan prediksi tingkat pengembalian (return).

Tingkat risiko dan tingkat return dinyatakan memiliki hubungan positif dan linear. Ukuran risiko yang merupakan indikator kepekaan saham dalam CAPM ditunjukkan oleh variabel $\beta$ (Beta). Semakin besar $\beta$ suatu saham, maka semakin besar pula risiko yang terkandung di dalamnya. Tingkat pengembalian pasar yang digunakan adalah tingkat pengembalian rata-rata dari kesempatan investasi di pasar modal (indeks pasar).
Penelitian ini diambil berdasarkan data yang tersedia di Bursa Efek Indonesia (BEI), khususnya terhadap saham-saham yang terdaftar di indeks Bisnis-27. Indeks Bisnis-27 adalah suatu indeks saham yang secara resmi diluncurkan oleh Bursa Efek Indonesia berkerja sama dengan harian Bisnis Indonesia yang terdiri dari 27 saham Perusahaan. Penelitian ini bertujuan untuk menganalisis pilihan investasi yang terbaik pada saham Indeks Bisnis-27 di Bursa Efek Indonesia (BEI) menurut pendekatan Capital Asset Pricing Model (CAPM) dilihat dari sisi risiko dan returnnya.

Berdasarkan uraian di atas, maka penulis tertarik untuk melakukan penelitian dengan judul: Analisis Capital Asset Pricing Model (CAPM) sebagai dasar Pengambilan Keputusan Berinvestasi Saham (Studi pada Saham Indeks Bisnis-27 di Bursa Efek Indonesia).

\section{Investasi}

Investasi adalah komitmen atas sejumlah dana atau sumber daya lainnya yang dilakukan pada saat ini, dengan tujuan memperoleh sejumlah keuntungan di masa yang akan datang. Seorang investor membeli sejumlah saham saat ini dengan harapan memperoleh keuntungan dari kenaikan harga saham atau pun sejumlah dividen dimasa yang akan datang, sebagai imbalan atas waktu dan risiko yang terkait dengan investasi tersebut (Tandelilin, 2001). 


\section{Saham}

Saham didefinisikan sebagai tanda penyertaan atau pemilikan sesorang atau badan dalam suatu perusahaan (Sunariyah, 2006). Arti lain dari saham adalah bagian kepemilikan dalam suatu perusahaan (Bodie,2014). Berdasarkan dua pengertian diatas, dapat ditarik suatu kesimpulan bahwa definisi saham adalah bukti/tanda kepemilikan investor terhadap suatu perusahaan.

\section{Return Investasi}

Menurut Jogiyanto (2009), Return merupakan hasil yang diperoleh dari investasi. Berdasarkan definisi para ahli tersebut, dapat ditarik sebuah kesimpulan bahwa return adalah tingkat pengembalian atau hasil keuntungan yang diperoleh dari investasi yang dilakukan.

\section{Risiko Investasi}

Risiko adalah kerugian yang dihadapi oleh para investor (Fabozzi,1995). Risiko merupakan kemungkinan terjadinya peristiwa yang tidak menguntungkan (Brigham and Weston, 1990).

\section{Capital Asset Pricing Model (CAPM)}

Capital Asset Pricing Model (CAPM) pertama kali diperkenalkan oleh Sharpe, Lintner, dan Mossin pada pertengahan tahun 1960-an. Melakukan estimasi atau perkiraan terhadap besarnya return sekuritas merupakan hal yang harus dilakukan oleh para investor

\section{Metode Penelitian}

Penelitian ini tergolong dalam penelitian deskriptif kuantitatif. Penelitian deskriptif adalah membuat penggambaran secara sistematis, faktual, dan akurat mengenai fakta-fakta dan sifat-sifat populasi atau daerah tertentu (Suryabrata, 1983). Variabel yang diteliti yaitu Return saham dan risiko sistematis. Populasi dari penelitian ini adalah seluruh perusahaan yang konsisten masuk ke dalam Indeks Bisnis-27 di Bursa Efek Indonesia Periode 2016 - 2017.

Perhitungannya dilakukan dengan menggunakan program Microsoft Excel. Analisis penerapan metode CAPM dalam menentukan investasi dilakukan dengan cara :

a) Mengumpulkan data saham yang masuk dalam Indeks Bisnis-27 pada periode 2014 - 2017, yaitu data closing price pada akhir bulan.

b) Menghitung tingkat keuntungan masing-masing saham.

$$
R_{i}=\frac{P_{t}-P_{t-1}}{P_{t-1}}
$$

c) Menghitung tingkat keuntungan tingkat keuntungan pasar.

$$
R_{m}=\frac{I H S G_{t}-I H S G_{t-1}}{I H S G_{t-1}}
$$

d) Menghitung Beta saham 


$$
\beta=\sum_{t-1}^{N} \frac{\left(R_{i}-\bar{R}_{i}\right)\left(R_{m}-\bar{R}_{m}\right)}{\left(R_{m}-\bar{R}_{m}\right)}
$$

e) Menghitung tingkat pengembalian bebas resiko $\left(\mathrm{R}_{\mathrm{f}}\right)$ melalui $\mathrm{BI}$ rate bulanan

f) Menghitung tingkat keuntungan yang diharapkan menurut CAPM

$$
\mathrm{E}\left(\mathrm{R}_{\mathrm{i}}\right)=\mathrm{R}_{\mathrm{f}}+\beta_{\mathrm{i}}\left[\mathrm{E}\left(\mathrm{R}_{\mathrm{m}}\right)-\mathrm{R}_{\mathrm{f}}\right]
$$

Penilaian saham berdasarkan tingkat pengembalian individu dan expected return diklasifikasikan sebagai saham efisien dan saham tidak efisisen.

\section{Hasil Penelitian}

Indeks BISNIS-27 terdiri dari 27 saham yang dipilih berdasarkan kriteria yang sudah ditentukan. Review dan penggantian saham dilakukan setiap 6 bulan yaitu pada bulan Mei dan November.

\section{Perusahaan yang konsisten masuk dalam}

Indeks Bisnis-27 Periode Penelitian

\begin{tabular}{ccc}
\hline No & $\begin{array}{c}\text { Kode } \\
\text { Saham }\end{array}$ & Nama Emiten \\
\hline 1 & AALI & Astra Agro Lestari \\
2 & ADRO & Adoro Energy \\
3 & AKRA & AKR Corporindo \\
4 & ASII & Astra International \\
5 & BBCA & Bank Central Asia \\
6 & BBNI & Bank Negara Indonesia \\
7 & BBRI & Bank Rakyat Indonesia \\
8 & BMRI & Bank Mandiri \\
9 & BSDE & Bumi Serpong Damai \\
10 & CPIN & Charoen Pokphand Indonesia \\
11 & GGRM & Gudang Garam \\
12 & INDF & Indofood Sukses Makmur \\
13 & INTP & Indocement Tungal Prakarsa \\
14 & KLBF & Kalbe Farma \\
\hline
\end{tabular}

\begin{tabular}{clc}
\hline 15 & PGAS & Perusahaan Gas Negara \\
16 & PWON & Pukuwo Jati \\
17 & SMGR & Semen Indonesia Persero \\
18 & TLKM & Telekomunikasi Indonesia \\
19 & UNTR & United Tractors \\
\hline
\end{tabular}

\section{Hasil Analisis Tingkat Pengembalian Saham Individu $\left(\mathbf{R}_{\mathbf{i}}\right)$}

Tingkat pengembalian saham individu dapat dihitung dengan cara membandingkan harga penutupan saham (closing price) bulan ini yang dinotasikan dengan bulan ke-t dikurangi dengan harga penutupan saham bulan kemarin yang dinotasikan dengan bulan ke t-1 kemudian dibagi dengan harga penutupan saham bulan ke t-1.

\begin{tabular}{ccc}
\hline No & Kode Emiten & $\mathbf{R}_{\mathbf{i}}$ \\
\hline 1 & AALI & 0.00476 \\
2 & ADRO & -0.00823 \\
3 & AKRA & 0.02793 \\
4 & ASII & -0.0305 \\
5 & BBCA & 0.01510 \\
6 & BBNI & 0.01177 \\
7 & BBRI & 0.01613 \\
8 & BMRI & 0.01153 \\
9 & BSDE & 0.01290 \\
10 & CPIN & 0.02399 \\
11 & GGRM & 0.01136 \\
12 & INDF & 0.00671 \\
13 & INTP & 0.01147 \\
14 & KLBF & 0.00323 \\
15 & PGAS & 0.01254 \\
16 & PWON & 0.00056 \\
17 & SMGR & 0.01551 \\
18 & TLKM & -0.00632 \\
19 & UNTR & -0.01938 \\
\hline
\end{tabular}


Pada tabel terlihat bahwa AKR Corporindo

Tbk, mendapat tingkat pengembalian saham individu (Ri) tertinggi sebesar 0.02793. Sedangkan Telekomunikasi Indonesia Persero mendapat tingkat pengembalian saham individu (Ri) terendah sebesar -0.0063 .

\section{Hasil Analisis Tingkat Pengembalian Pasar $\left(\mathbf{R}_{\mathbf{M}}\right)$}

Tingkat pengembalian pasar merupakan tingkat pengembalian yang didasarkan pada perkembangan indeks saham. Return pasar dihitung dengan cara mengukur selisih Indeks pasar Bisnis-27 pada bulan sekarang (Bisnis-27t) dengan bulan sebelumnya (Bisnis-27t-1) kemudian dibagi dengan IHSG bulan sebelumnya (Bisnis-27t-1).

Hasil Analisis Risiko Sistematis Masingmasing Saham Individu $\left(\beta_{\mathrm{i}}\right)$

\begin{tabular}{ccc}
\hline No & Kode Emiten & $\boldsymbol{\beta}_{\mathbf{i}}$ \\
\hline 1 & AALI & 0.006 \\
2 & ADRO & 0.671 \\
3 & AKRA & 1.911 \\
4 & ASII & 1.332 \\
5 & BBCA & 0.947 \\
6 & BBNI & 1.381 \\
7 & BBRI & 1.582 \\
8 & BMRI & 1.486 \\
9 & BSDE & 1.566 \\
10 & CPIN & 1.713 \\
11 & GGRM & 0.378 \\
12 & INDF & 0.838 \\
13 & INTP & 0.890 \\
\hline
\end{tabular}

\begin{tabular}{rrr}
\hline 14 & KLBF & 0.561 \\
15 & PGAS & 0.743 \\
16 & PWON & 1.575 \\
17 & SMGR & 1.374 \\
18 & TLKM & 1.484 \\
19 & UNTR & 0.390 \\
\hline & Jumlah & $\mathbf{2 0 . 8 2 8}$ \\
& Rata-rata & $\mathbf{1 . 0 9 6}$ \\
\hline
\end{tabular}

Hasil perhitungan menunjukkan rata-rata $\beta_{i}$ bernilai lebih dari $1(1,096>1)$ sehingga secara umum 19 saham perusahaan yang dijadikan sampel penelitian memiliki risiko sistematis yang tinggi dan cenderung aktif dalam merespon perubahan harga pasar. Sebagai contoh adalah saham Astra Agro Lestari (AALI) memiliki $\beta$ i terendah yaitu sebesar 0.006 serta tingkat pengembalian yang diharapkan tertinggi sebesar 0.00565 yang menunjukkan bahwa saham tersebut memiliki risiko yang kecil, cenderung pasif dan kurang peka terhadap perubahan harga pasar. Sedangkan saham AKR Corporindo Tbk (AKRA) memiliki $\beta_{\text {i tertinggi yaitu }}$ sebesar 1.911 dan menunjukkan $\mathrm{E}\left(\mathrm{R}_{\mathrm{i}}\right)$ terendah sebesar $0,00701 \quad$ yang menunjukkan bahwa saham tersebut memiliki risiko yang besar, sangat aktif dan sangat peka terhadap perubahan harga pasar.

\section{Pengelompokan Saham-saham efisien dan Keputusan Investasi}

Saham efisien adalah saham dengan tingkat pengembalian individu lebih besar 
daripada tingkat pengembalian yang diharapkan $[(\mathrm{Ri})>\mathrm{E}(\mathrm{Ri})]$. Saham tidak efisien adalah saham dengan tingkat pengembalian individu lebih kecil daripada tingkat pengembalian yang diharapkan $[(\mathrm{Ri})<\mathrm{E}(\mathrm{Ri})]$.

\section{Daftar Saham Efisien dan Tidak Efisien}

yang tidak efisien. Kriteria dalam menentukan keputusan investasi yaitu memilih saham efisien, saham-saham yang mempunyai return individu lebih besar dari tingkat pengembalian yang diharapkan (Ri>ERi) sedangkan mengeliminasi saham tidak efisien yaitu saham yang mempunyai nilai return individu lebih kecil dari tingkat

\begin{tabular}{|c|c|c|c|c|c|}
\hline \multirow[b]{2}{*}{ No } & \multicolumn{4}{|c|}{ Kode } & \multirow{2}{*}{$\begin{array}{c}\text { Evaluasi } \\
\text { Saham }\end{array}$} \\
\hline & Nama Emiten & Emiten & $\mathbf{R i}$ & $\mathbf{E}(\mathbf{R i})$ & \\
\hline 1 & Astra Agro Lestari & AALI & 0.00476 & 0.00565 & Tidak Efisien \\
\hline 2 & Adoro Energy & ADRO & -0.0082 & 0.0061 & Tidak Efisien \\
\hline 3 & AKR Corporindo & AKRA & 0.02793 & 0.00701 & Efisien \\
\hline 4 & Astra International & ASII & -0.0305 & 0.00658 & Tidak Efisien \\
\hline 5 & Bank Central Asia & BBCA & 0.0151 & 0.0063 & Efisien \\
\hline 6 & Bank Negara Indonesia & $\mathrm{BBNI}$ & 0.01177 & 0.00662 & Efisien \\
\hline 7 & Bank Rakyat Indonesia & BBRI & 0.01613 & 0.00676 & Efisien \\
\hline 8 & Bank Mandiri & BMRI & 0.01153 & 0.00669 & Efisien \\
\hline 9 & Bumi Serpong Damai & BSDE & 0.0129 & 0.00675 & Tidak Efisien \\
\hline 10 & Charoen Pokphand Indonesia & CPIN & 0.02399 & 0.00686 & Efisien \\
\hline 11 & Gudang Garam & GGRM & 0.01136 & 0.00589 & Efisien \\
\hline 12 & Indofood Sukses Makmur & INDF & 0.00671 & 0.00622 & Efisien \\
\hline 13 & Indocement Tungal Prakarsa & INTP & 0.01147 & 0.00626 & Efisien \\
\hline 14 & Kalbe Farma & KLBF & 0.00323 & 0.00602 & Tidak Efisien \\
\hline 15 & Perusahaan Gas Negara Persero & PGAS & 0.01254 & 0.00615 & Efisien \\
\hline 16 & Pukuwo Jati & PWON & 0.00056 & 0.00676 & Tidak Efisien \\
\hline 17 & Semen Indonesia Persero & SMGR & 0.01551 & 0.00661 & Efisien \\
\hline 18 & Telekomunikasi Indonesia & TLKM & -0.0063 & 0.00669 & Tidak Efisien \\
\hline 19 & United Tractors & UNTR & -0.0194 & 0.00589 & Tidak Efisien \\
\hline
\end{tabular}


mempertimbangkan untuk membeli sahamsaham tersebut, dan keputusan investasi yang dilakukan terhadap saham-saham tidak efisien / not good yaitu mempertimbangkan untuk menjual saham-saham tersebut.

\section{Pembahasan}

Pada dasarnya penelitian ini membuktikan bahwa Analisis Capital Asset Pricing Model (CAPM) mampu membantu para investor menentukan keputusan berinvestasi. CAPM membantu investor mengestimasi tingkat keuntungan yang diharapkan dengan memperhatikan sejauh mana risiko sistematis yang mungkin terjadi.

Setiap investor memiliki karakteristik masing-masing yang dalam kenyataannya investor berupaya memilih investasi yang berisiko lebih kecil jika dihadapkan pada dua pilihan investasi yang memberikan return yang sama dengan risiko yang berbeda. Dalam penelitian ini menjelaskan bahwa investor dapat menggunakan CAPM untuk menilai hubungan antara risiko dan return, selain itu beta juga digunakan dalam metode CAPM sebagai alat ukur untuk mengukur hubungan antara tingkat pengembalian investasi dengan tingkat pengembalian pasar secara keseluruhan.

Investor yang rasional melakukan keputusan investasi yang didasari dengan menganalisis situasi saat ini, mendesain portofolio optimal, menyusun kebijakan investasi, mengimplementasikan strategi investasi, memonitor dan melakukan supervisi pada kinerja khusus para manajer keuangan.

Portofolio optimal dapat ditentukan dengan menggunakan model indeks tunggal, maka yang pertama kali dibutuhkan adalah menentukan portofolio efisien. Portofolio yang efisien didefinisikan sebagai portofolio yang memberikan ekspektasi terbesar dengan risiko yang tertentu atau memberikan risiko yang terkecil dengan return ekspektasi tertentu.

\section{Kesimpulan}

Terdapat hubungan nonlinear antara risiko sistematis dengan tingkat pengembalian saham yang diharapkan. Sebagai contoh adalah saham Astra Agro Lestari (AALI) memiliki $\beta$ i terendah yaitu sebesar 0.006 serta tingkat pengembalian yang diharapkan tertinggi sebesar 0.00565 . Sedangkan saham AKR Corporindo Tbk (AKRA) memiliki $\beta$ i tertinggi yaitu sebesar 1.911 dan menunjukkan $\mathrm{E}(\mathrm{Ri})$ terendah sebesar 0,00701. Rata-rata $\beta$ i bernilai lebih dari $1(1,096>1)$ sehingga secara umum 19 saham perusahaan yang dijadikan sampel penelitian memiliki risiko sistematis yang tinggi dan cenderung aktif dalam merespon perubahan harga pasar. 
Terdapat 11 saham perusahaan yang termasuk dalam kategori saham efisien dan 8 saham perusahaan yang termasuk dalam kategori saham tidak efisien dari 19 saham perusahaan yang dijadikan sampel penelitian. Saham- saham perusahaan yang termasuk dalam kategori saham efisien antara lain : saham AKRA, BBCA, BBNI, BBRI, BMRI, CPIN, GGRM, INDF, INTP, PGAS, SMGR. Saham-saham tersebut memiliki nilai Ri lebih besar daripada $\mathrm{E}(\mathrm{Ri})$ atau $[\mathrm{Ri}>\mathrm{E}(\mathrm{Ri})]$. Keputusan investasi yang harus diambil oleh investor adalah membeli saham tersebut. Sedangkan 8 saham yang masuk dalam kategori saham tidak efisien antara lain : saham AALI, ADRO, ASII, BSDE, KLBF, PWON, TLKM, UNTR. Saham-saham tersebut memiliki nilai $\mathrm{Ri}$ lebih kecil daripada $\mathrm{E}(\mathrm{Ri})$ atau $[\mathrm{Ri}<$ $\mathrm{E}(\mathrm{Ri})]$. Keputusan investasi yang harus diambil oleh investor adalah menjual saham tersebut sebelum harga turun.

\section{Saran}

Penelitian ini diharapkan dapat dijadikan referensi dan tambahan informasi bagi para investor maupun calon investor yang akan melakukan investasi saham. Sangat penting bagi investor untuk menginvestasikan kelebihan dana yang dimiliki pada saham-saham yang efisien agar risiko yang akan dihadapi dapat diminimalisir dengan baik, sehingga tujuan investor untuk mendapatkan return yang diharapkan dapat tercapai.
Penelitian dengan metode CAPM ini diharapkan dapat dijadikan referensi untuk penelitian selanjutnya dengan sampel dan periode penelitian yang berbeda, sehingga perkembangan mengenai pasar modal khususnya investasi saham dapat selalu diketahui.

\section{Daftar Pustaka}

Aditya, Rendhi dan Ririn Irmadariani. (2014). Analisis Risiko dan Return Saham dengan menggunakan metode CAPM untuk Menentukan Pilihan Berinvestasi pada Saham LQ45 di BEI. Jurnal Akuntansi Fakultas Ekonomi. Universitas Jember.

Deny Saputra, Wildan (2013). Penggunaan metode Capital Asset Pricing Model dalam menentukan saham efisien. Jurnal Administrasi Bisnis $(J A B)$. Universitas Brawijaya.

Fahmi, Irham. (2012). Manajemen Investasi (Teori dan Soal Jawab). Bandung: Alfabeta.

Halim, Abdul. (2005).Analisis Investasi. Edisi Kedua. Jakarta: Salemba Empat.

Sugiyono. (2013). Metode Penelitian Kuantitatif Kualitatif dan $R \& D$. Bandung:Alfabeta.

Sunariyah. (2010). Pengantar Pengetahuan Pasar Modal. Edisi ke enam. Yogyakarta: UPP-AMP YKPN 